\title{
The Assessment of Selected Mechanical Properties of Steel after Application of Plasma Nit- riding
}

David Dobrocký, David Kusmič

Faculty of Military Technology, University of Defence in Brno. Kounicova 65, 66210 Brno. Czech Republic. E-mail: david.dobrocky@unob.cz,david.kusmic@unob.cz

The article deals with mechanical properties of plasma nitrided steel. Experimental work was focused on evaluation of influence of plasma nitriding process to notch toughness of steel, the experimental were realised on V-notch samples of size 10x10x55 mm (according to CSN ISO 148-1 standard). Nitrided layers were applied to steel $30 \mathrm{CrMoV9}$ which were subsequently evaluated by metallographic, GDOES and microhardness method. The notch toughness tests of steel were carried out using the instrumental Charpy hammer at temperatures $-40{ }^{\circ} \mathrm{C},+21^{\circ} \mathrm{C}$ and $+70{ }^{\circ} \mathrm{C}$. The results of experiments showed that plasma nitriding process has a direct impact on change of notch toughness parameters. The notch toughness of plasma nitrided steel was significantly decreased. The measurements thereinafter showed that values of notch toughness at low temperature $\left(-40{ }^{\circ} \mathrm{C}\right)$ decreased but also at higher temperature $\left(+70^{\circ} \mathrm{C}\right)$. It was found a dependence of notch toughness values of plasma nitrided steel between the testing temperature and plasma nitriding process parameters.

Keywords: Plasma Nitriding, Notch Toughness, V-notch

\section{Acknowledgement}

The paper was prepared with the support of the Project for the Development of the Organization and by the Specific research project 2014 of the Department of Mechanical Engineering, UoD "Promoting Research, Science and Innovation in the Field of Engineering".

\section{References}

[1] BINAR, T., KADLEC, J., REJZEK, M, VLKOVSKY, M., HRUBY, V. (2011). Evaluation of the test temperature effect on failure mechanisms and notched impact strength characteristics of ultra-hard low alloy steels. In: Strength of Materials, Vol. 43, No. 5, pp. $537-542$.

[2] AKBARI, A., MOHAMMADZADEH, R., TEMPLIER, C., RIVIERE, J. P. (2010). Effect of the initial microstructure on the plasma nitriding behaviour of AISI M2 hihg speed steel. In: Surface and Coatings Technology, vol 204, 2010, pp. 4114-4120.

[3] KADLEC, J., DVOŘÁK, M. (2008). Duplex surface treatment of stainless steel $\mathrm{X}_{12} \mathrm{CrNi}_{18.8}$. In: Strength of Materials, vol. 40, 2008, pp. 118-121.NOVY, L. (1996). Sample paper. In: Sample Journal, Vol. 3, No. 1, pp. 9 15. TTP. Switzerland.

[4] SIRIN, S. Y., SIRIN, K., KALUC, E. (2008). Effect of the ion nitriding surface hardening proces on fatigue behaviour of AISI 4340 steel. In: Materials Characterization, Vol. 59, 2008, pp. 351-358.

[5] DOBROCKÝ, D., DOAN, T., KUSMIČ, D., HRUBÝ, V. (2014). The Change of Notch Toughness Parameters of Steel After Plasma Nitriding. In: ICMT'- 2014, pp. 66-74.

[6] DOBROCKÝ, D., KUSMIČ, D. (2015). The Effect of Plasma Nitriding Process on the Change of Dynamic Parameters of Steel DIN 1654/4. In: Manufacturing Technology, Vol. 15, No. 1, pp. $14-20$.

[7] ISO 148-1:2009Metallic materials - Charpy pendulum impact test - Part 1: Test method

[8] ISO 14556:2000Steel - Charpy V-notch pendulum impact test - Instrumented test method

[9] DIN 50190-3 - Hardness depth of heat-treated parts; determination of the effective depth of hardening after nitriding. Deutsches Institut für Normung E. V., 1979.

[10] POKORNÝ, Z., KADLEC, J., HRUBÝ, V., JOSKA, Z., TRAN, D. Q. (2011). Mechanical Properties of Steels after Plasma Nitriding Process. In: Journal of Materials Science and Engineering, Vol. A1, pp. 42-45.

[11] HOLEMÁř, A., HRUBÝ, V. (1989). Iontová nitridace v praxi. SNTL, Praha 1989, pp. 178-180.

[12] PYE, D. (2003). Practical nitriding and ferritic nitrocarburizing. $2^{\text {nd }}$ edition, Ohio: ASM International Materials Park 2003, pp. 127-129.

[13] LATTNER, M., HOLESOVSKY, F. (2014). Effect of Machining the Load Capacity Notched Components. In: Manufacturing Technology, vol. 14, 2014, pp. 47-50.

[14] MADL, J., RAZEK, V., KOUTNY, V., KAFKA, J. (2013): Surface Integrity in Notches Machining. In: Manufacturing Technology, vol. 13, 2013, pp. 188-193. 